\title{
Development of Voltammetry Analysis Method of Copper Metal lons by Solid-State Membrane with Carbon Nanotube
}

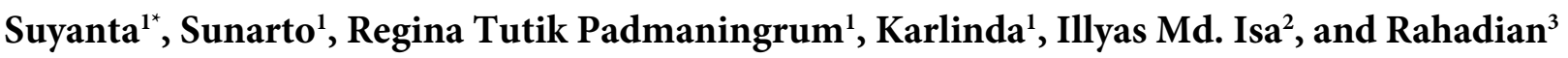 \\ ${ }^{1}$ Department of Chemistry Education, Universitas Negeri Yogyakarta, Jl. Colombo No. 1, Yogyakarta 55281, Indonesia \\ ${ }^{2}$ Nanotechnology Research Centre, Faculty of Science and Mathematics, Universiti Pendidikan Sultan Idris, \\ 35900 Tanjong Malim, Perak, Malaysia \\ ${ }^{3}$ Department of Chemistry, Faculty of Mathematics and Natural Sciences, Universitas Negeri Padang, \\ Jl. Prof. Dr. Hamka, Padang 25173, West Sumatera, Indonesia
}

*Corresponding author:

tel: +62-81227577355

email:suyanta@uny.ac.id

Received: March 26, 2020

Accepted: November 2, 2020

DOI: $10.22146 /$ ijc.55056

\begin{abstract}
This study was aimed to develop a method for metal analysis in continuous integration using voltammetry techniques. The research subject was copper(II) ions. The objects of research were linearity, scan rate, repeatability of readings, and the presence of $\mathrm{Cu}(I I)$ levels in well water samples. In this study, a selective electrode was developed with a solid membrane voltammetry system using differential pulse voltammetry measurement. The results showed the regression line of voltammetry method, $y=10.265$ $\ln (x)+330.47$, with a correlation value of 0.9654 , the optimum scan rate was $10 \mathrm{mV} / \mathrm{s}$, and within five repetitions of each measurement for one electrode, it showed good repeatability. Meanwhile, the result of regression with the UV-Vis spectrophotometric method for $\mathrm{Cu}(\mathrm{II})$ was $y=0.12386 x+0.00879$ with a correlation value of 0.9943 . The voltammetry method was found to be much better than the UV-Vis method because it was able to be used for analysis up to a concentration of $6.35 \times 10^{-4} \mathrm{ppm}$ (or $1.00 \times 10^{-11}$ $M)$, while the UV-Vis method was only able to analyze up to $1.5 \mathrm{ppm}$ (or $2.36 \times 10^{-5} \mathrm{M}$ ).
\end{abstract}

Keywords: copper(II); spectrophotometry; voltammetry; nanotube carbon; solid-state membrane

\section{- INTRODUCTION}

Disposal of both industrial and domestic production processes usually results in environmental pollution. Metals commonly found in chemical industrial wastes are copper, silver, cadmium, cobalt, iron, chromium, nickel, and zinc [1]. Copper $(\mathrm{Cu})$ is extensively used in the chemical industry, particularly in electroplating, textile, and metal industries. Copper(II) sulfate is usually used for chemical analysis reagent, organic compound synthesis, additives in NPK fertilizer, blue dyeing in the textile industry, etc. Copper is one of the heavy metals that is toxic and dangerous [2].

Many techniques have been developed to detect the content of copper (ion) in many samples using instruments such as UV-VIS spectrophotometers, AAS, ICP-MS, and ICP-AES. The AAS method is less sensitive for the determination of rare earth elements because of the high detection limit, which is $800-900$ ppm, while ICP-MS and ICP-AES methods require very expensive devices [3]. Because of the limitations of these methods, another method is needed for better copper determination. The Potentiometry method with the use of ion-selective electrodes as working electrodes is a fairly inexpensive and practical analysis method, that can provide good sensitivity and selectivity. Based on a previous study [4], copper electrodes were found to be quite sensitive with a detection limit reaching $10^{-9} \mathrm{~mol} / \mathrm{L}$. Ganjali et al. [5] had synthesized a particular compound made of 4-methyl-hidrazino benzothiazole hydrobromide and hydrazine hydrate. This compound has a complex set of copper and iron, so it was able to selectively react with copper and iron. 
The development of the analysis of metal ions including copper(II) using voltammetry has been carried out, both ionically and molecularly in compounds, especially with electrometry systems [6-8]. The development of voltammetry analysis techniques using carbon nanotubes has also been developed. The voltammetric determination of cadmium, iron and lead was carried out by Deswati et al. [9]. The determination of several heavy metal ions by means of differential anodic stripping voltammetry pulse was conducted by Thanh et al. [10] and the development of the analysis of $\mathrm{Cd}, \mathrm{Cu}, \mathrm{Pb}$, and $\mathrm{Zn}$ ions in seawater was carried out by Deswati et al. [11].

The use of carbon nanotubes as an ion selective electrode is not only for the analysis of metal ions, but also for the analysis of non-metals, especially organic compounds. The analysis of phenols and their derivatives by voltammetry using carbon nanotubes was developed by Adekunle et al. [12], while the determination of voltammetric tyrosine, acetaminophen and ascorbic acid compounds with carbon nanotube electrodes was developed by Madrakian et al. [13]. Meanwhile, the detection of glutamate at a biosensor of carbon nanotube electrodes was studied by Khan et al. [14].

Copper determination by UV-VIS technique generally uses various complexing compounds. The complexes used include ferrocene [15], which was researched by Zubair et al. [16]. Another compound that has a similar structure is Na-diethyldithiocarbamate or Na-DDTC with the molecular formula of $\left(\mathrm{C}_{2} \mathrm{H}_{5}\right)_{2} \mathrm{NCS}_{2} \mathrm{Na}$. Sirotiak [17] in his research, stated that copper is one of the many elements that can form complexes with sodium diethyldithiocarbamate (NaDDTC). Therefore, in this study, the copper ion-selective electrode was developed by Na-diethyldithiocarbamate as an active ingredient of the membrane and the basic matrix of carbon nanotubes and analyzed by means of differential pulse voltammetry.

\section{- EXPERIMENTAL SECTION}

The subject of this study was copper(II) ions in well water and the objects were linearity, scan rate, repeatability of readings, and the presence of $\mathrm{Cu}(\mathrm{II})$ levels in well water samples.

\section{Materials}

All reagents used in this study were of analytical reagent grade. Carbon nanotube powder (Timesnano) and paraffin (Uvasol, Merck), copper(II) sulfate (SigmaAldrich), Na-diethyldithiocarbamate (Merck), potassium chloride (Merck), and potassium nitrate (Merck) were used as received. Stock solutions of copper ions were freshly prepared by dissolving an appropriate amount of copper(II) sulfate in distilled deionized water. The samples of well water were collected from some areas in the Yogyakarta State University, Indonesia.

\section{Instrumentation}

The differential pulse voltammetry was performed with EDAQ Potentiostat, (Australia). All experiments were carried out in a single compartment electrochemical cell with a carbon-paste working electrode, saturated $\mathrm{Ag} / \mathrm{AgCl}$ reference electrode and $\mathrm{Pt}$ wire counter electrode. The reference and counter electrodes refer to previous research conducted by Farahi et al. [18]. These electrodes were immersed in $40 \mathrm{~mL}$ buffer solution (also as supporting electrolytes) at various $\mathrm{pH}$ and amount of $\mathrm{Cu}$ (II) solution. The $\mathrm{pH}$ value was determined using a glass electrode Orion 915600, USA. The spectroscopy method was conducted using Spectrophotometer UV-VIS Shimadzu, 2450 Series.

\section{Procedure}

\section{Electrode preparation}

The modified carbon paste electrodes were a homogenized mixture of Na-diethyldithiocarbamate, carbon nanotube, and solid paraffin with a ratio of 4:3:3 in mass composition in paste form. The modified carbon paste electrodes were packed firmly into a teflon tubing (id $=4 \mathrm{~mm}$ ). Electrical contact to the paste was established via a copper wire at one end of the tubing, while the other end acted as the disc electrode. Before measurement, the disc electrode was smoothened on a piece of weighing paper. This method refers to Suyanta [19].

\section{Voltammetry analysis}

The copper(II) ion analysis was developed using differential pulse voltammetry. This technique was found to be useful in analyzing metal ions. This 
technique was developed by several researchers [20-21]. With differential pulse voltammetry techniques, the current is measured at two points for each pulse, just before the application of the pulse and at the end of the pulse. The difference between the two measured currents for each pulse is plotted against the base potential [22]. Voltammetry data in the form of peak adsorption currents were changed in the current study because of the various scan rate, repeatability and various concentration studied in this research.

The conditions applied during the accumulation of the analyte including accumulation of potential (initial $-1000 \mathrm{mV}$, final $0 \mathrm{mV}$ ), accumulation of time, and $\mathrm{pH}$ of the solution $(7,32)$ referred to the previous studies by Suyanta [19]. The conditions on the determination of $\mathrm{Cu}$ (II) by spectrophotometry (the maximum wavelength of $400-500 \mathrm{~nm}$ and $\mathrm{pH} 5-11$ ) refer to the thesis research by Niken and Sunarto [23].

\section{Data analysis}

The results of the study on solutions of various concentrations were determined by the linear concentration region and a calibration curve between the high currents of the peak versus the concentration. This analysis was done to determine the linearity and the correlation between the standard solution calibration curve and its samples. This analysis technique was used for the voltammetry and spectroscopy methods.

\section{- RESULTS AND DISCUSSION}

\section{Characterization of Copper(II) Carbon Paste Electrode System in Differential Pulse Voltammetry}

The active ingredient sodium diethyldithiocarbamate membrane as the modifier of the carbon paste electrode influenced the copper(II) voltammogram. The results of the voltammogram of the copper ion measurements are shown in Fig. 1.

Fig. 1 shows that the modified electrode of $\mathrm{Na}-$ diethyldithiocarbamate carbon paste gave a peak current response to copper(II) solution, at a potential of $-0.695 \mathrm{~V}$ vs. $\mathrm{Ag} / \mathrm{AgCl}$ with a current value of $102.636 \mathrm{nA}$, while an electrode without modification did not give any rise to a peak. Thus the electrode was able to censor the presence of copper(II) ions properly.
Carbon paste electrodes without modification did not produce $\mathrm{Cu}$ peaks because no complexation reactions occurred. While the carbon paste electrode with modification caused a complexation reaction between copper with sodium diethyldithiocarbamate (Na-DDTK) which produces a $\mathrm{Cu}$ peak.

The complexation reaction mechanism that occurred on the surface of the electrode is proposed as follows:

$$
\begin{aligned}
2 \mathrm{Cu}^{2+}{ }_{(\mathrm{aq})}+\mathrm{SO}_{4}^{2-}{ }_{(\mathrm{aq})} & +2 \mathrm{NH}_{3(\mathrm{aq})}+2 \mathrm{H}_{2} \mathrm{O}_{(\mathrm{l})} \\
\rightarrow & \rightarrow \mathrm{Cu}(\mathrm{OH})_{2} \cdot \mathrm{CuSO}_{4(\mathrm{~s})}+2 \mathrm{NH}_{4(\mathrm{aq})}^{+} \\
\mathrm{Cu}(\mathrm{OH})_{2} \cdot \mathrm{CuSO}_{4(\mathrm{~s})} & +8 \mathrm{NH}_{3(\mathrm{aq})} \\
\rightarrow & \rightarrow\left[\mathrm{Cu}\left(\mathrm{NH}_{3}\right)_{4}\right]_{(\mathrm{aq})}^{2+}+\mathrm{SO}_{4(\mathrm{aq})}^{2-}+2 \mathrm{OH}_{(\mathrm{aq})}^{-} \\
{\left[\mathrm{Cu}\left(\mathrm{NH}_{3}\right)_{4}\right]_{(\mathrm{aq})}^{2+}+2\left(\mathrm{C}_{2} \mathrm{H}_{5}\right)_{2} \mathrm{NCS}_{2} \mathrm{Na}_{(\mathrm{aq})} } & \rightarrow \mathrm{Cu}\left(\left(\mathrm{C}_{2} \mathrm{H}_{5}\right)_{2}\right]_{2(\mathrm{aq})}+\mathrm{Na}_{(\mathrm{aq})}^{+}+4 \mathrm{NH}_{4} \mathrm{OH}_{(\mathrm{aq})}
\end{aligned}
$$

The formula structure of the complex $\mathrm{Cu}(\mathrm{DDC})_{2}$ can be depicted as shown in Scheme 1 [24].

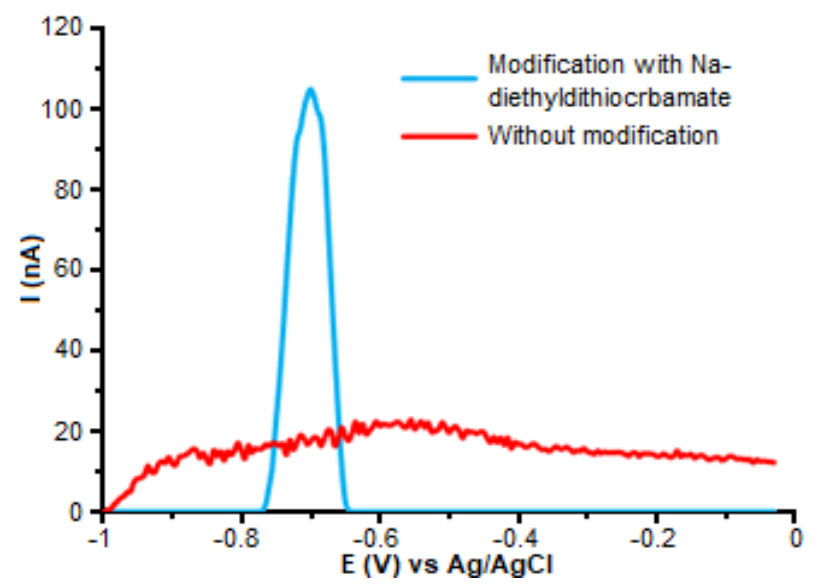

Fig 1. The difference in the voltammogram curve at the working electrode with and without $\mathrm{Na}$ diethyldithiocarbamate modification

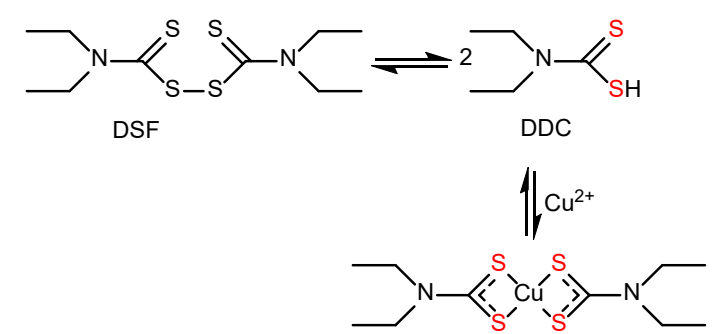

Scheme 1. Disulfiram (DSF) in aqueous solutions is reduced to diethyldithiocarbamate (DDC) and in the presence of $\mathrm{Cu}^{2+}$ forms bis(diethyldithiocarbamate) copper(II): $\mathrm{Cu}(\mathrm{DDC})_{2}$ 


\section{Linearity}

The linear concentration area of the modified carbon paste electrode was studied to determine the area (range) of concentration which provided a linear relationship between the height of the peak current and the concentration of copper(II) $\left(10^{-6}-10^{-10} \mathrm{M}\right)$. The corresponding voltammograms are shown in Fig. 2.

Based on Fig. 2, it appears that the presence of copper(II) ions at various concentrations can be censored by the electrode properly. The greater the concentration of copper(II) ions, the higher the voltammogram.

If the voltammogram in Fig. 2 created a relationship between the concentration and the measurement current value, a linear graph would be formed. The relationship between the concentration and the current is listed in Table 1.

Based on Table 1, a curve was made between the concentration of copper(II) solution and the height of the peak current produced. The result is shown in Fig. 3.

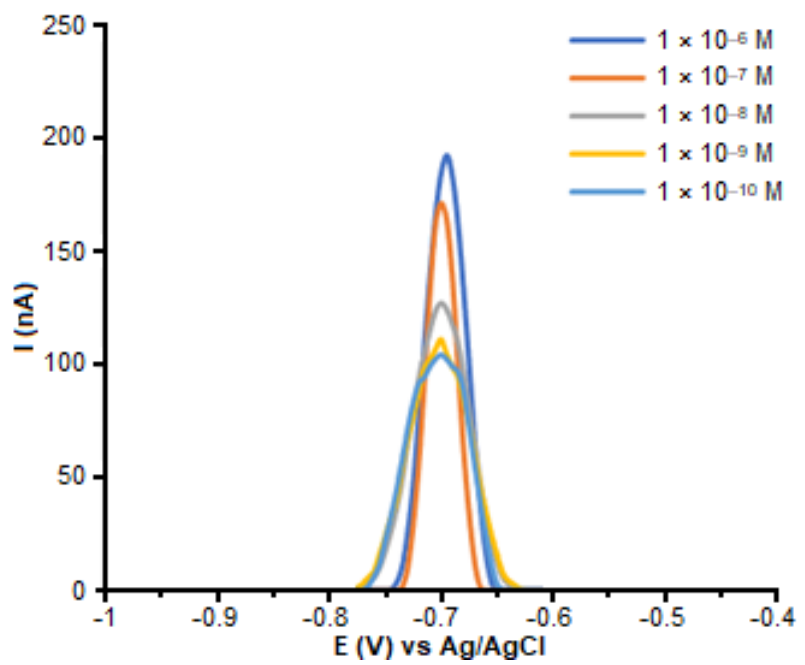

Fig 2. The voltammogram curve of the modified working electrode at various concentrations

Table 1. The measurement results of the copper(II) current at various concentrations

\begin{tabular}{cc}
\hline Concentration $(\mathrm{M})$ & Current $(\mathrm{nA})$ \\
\hline $1.0 \times 10^{-6}$ & 192.59 \\
$1.0 \times 10^{-7}$ & 171.37 \\
$1.0 \times 10^{-8}$ & 127.37 \\
$1.0 \times 10^{-9}$ & 111.04 \\
$1.0 \times 10^{-10}$ & 104.58 \\
\hline
\end{tabular}

Based on the results of this study, it can be seen that the current is comparable with the concentration. This relationship is mathematically expressed through the regression line equation which is calculated with the value, $y=10.265 \ln (x)+330.47$ and the value of $r=$ 0.9654 . The linearity of the UV-Vis spectroscopy method was expressed by the line equation, $y=0.12386 x$ +0.00879 , with the value of $r=0.9943$, as seen in the calibration curve shown in Fig. 4 [23].

The results of the study show the value of $r \geq 0.95$ which indicates a linear criterion for both techniques. Thus both techniques are good methods of analysis.

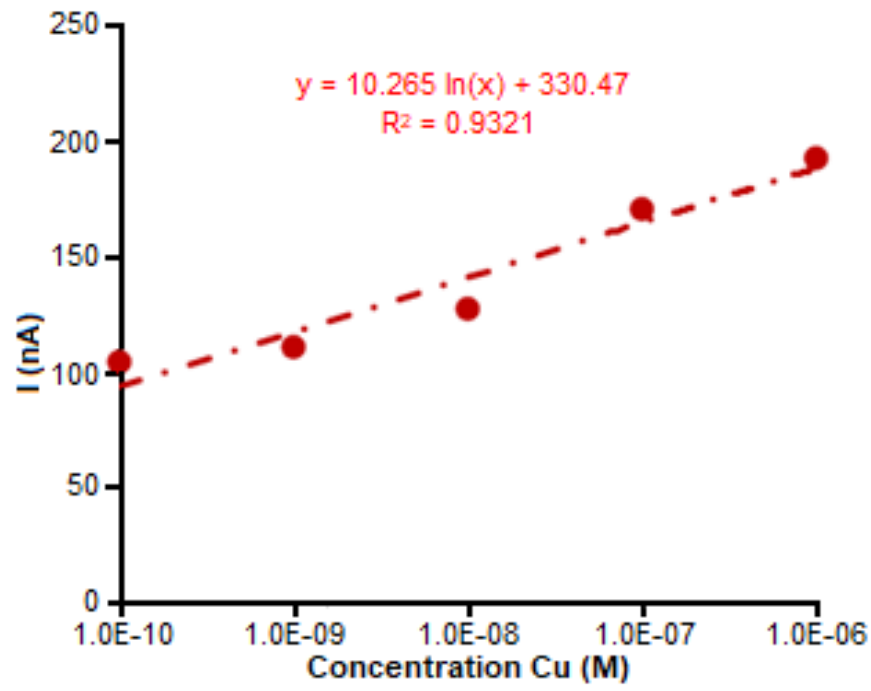

Fig 3. The relationship between the concentration of copper(II) solution and the high current

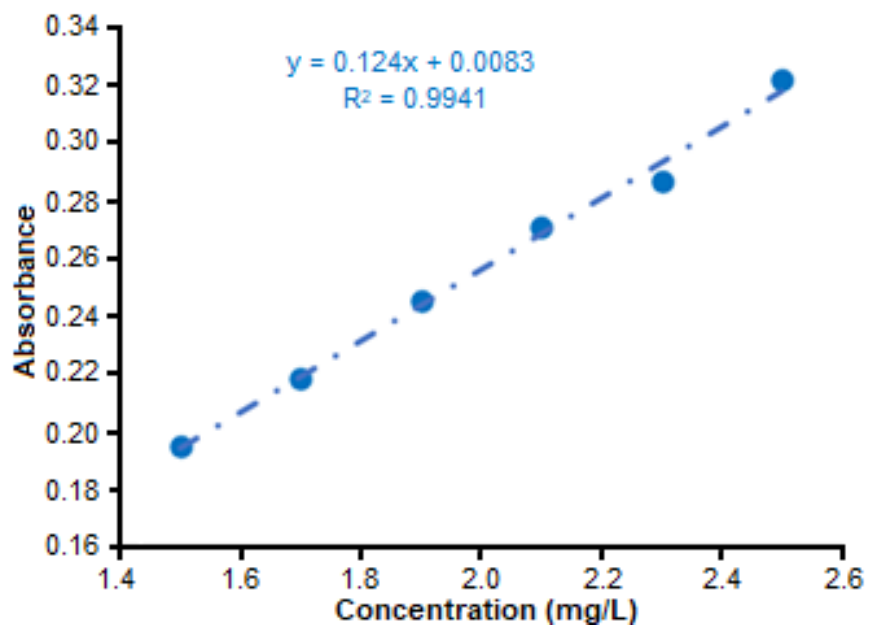

Fig 4. Copper(II)- diethyldithiocarbamate calibration curve 


\section{Scan Rate}

In differential pulse voltammetry, the height and width of the peak of the current are affected by the speed of reading [25]. The related measurement results are shown in Fig. 5.

Fig. 5 shows that the current produced by a concentration of $10^{-10} \mathrm{M}$ was lower than the data in Table 1 because the determination of maximum current was also different. In Fig. 1 and 2, the maximum current was $100 \mathrm{nA}$, while in Fig. 5 the maximum current was $50 \mathrm{nA}$, with $10 \mathrm{nA}$ difference between measurements $(10,20,30$, 40 and $50 \mathrm{nA}$ ). The choice of maximum current with a not so large difference between measurements resulted in no significant effect to the current generated. The scan rate selection in Fig. 5 refers to previous research conducted by Suyanta et al. [18]. The peak of the voltammogram in Fig. 5 shifted quite far to the more positive potential. This shows the kinetic limitations in the electrochemical reaction of $\mathrm{Cu}(\mathrm{II})$ in Na-DDTK modified carbon paste electrodes.

The results of the current measurements at various scan rates can be seen in Table 2 .

Table 2 shows that the higher the scan rate, the smaller the current value obtained. In this study, the optimum reading scan rate was $10 \mathrm{mV} / \mathrm{s}$ because the peak obtained was higher and not wider.

\section{Repeatability Results of the Electrode}

The repeatability of the modified carbon paste electrodes was studied by comparing the peak currents at optimum conditions. The measurements were carried out 5 times with one electrode under solution conditions and fixed measurements. The measurement results are shown in Fig. 6.

The results of the measurements that were repeated 5 times show that the peak current was stable (constant), indicating that the modified Na-diethyldithiocarbamate carbon paste electrode had a good reproducible repetition. According to Silva et al. [26], the electrodes that presented good precision showed that there was no matrice effect that affected the electrodes for detection.

\section{The Measurement Result of $\mathrm{Cu}$ (II) in the Well Water}

The Na-diethyldithiocarbamate modified electrode was applied to determine the content of copper(II) in well water. The results of the well water measurements are shown in Fig. 7.

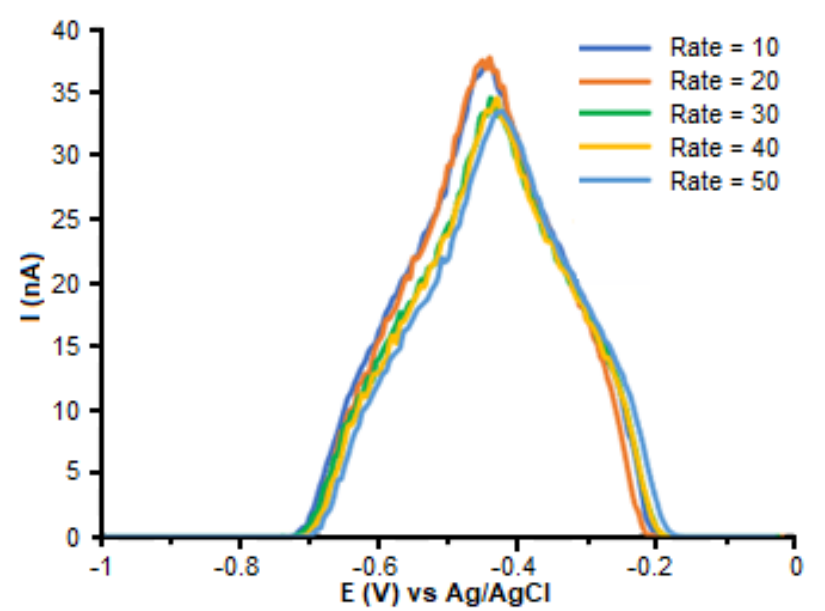

Fig 5. The effect of the difference in the adsorption rate of copper(II) from the modified working electrode at a concentration of $1 \times 10^{-10} \mathrm{M}$ and a maximum current of $50 \mathrm{nA}$

Table 2. The measurement results of the current at various scan rates

\begin{tabular}{cc}
\hline Scan Rate $(\mathrm{mV} / \mathrm{S})$ & Current $(\mathrm{nA})$ \\
\hline 10 & 37.02 \\
20 & 36.90 \\
30 & 34.67 \\
40 & 34.10 \\
50 & 33.52 \\
\hline
\end{tabular}

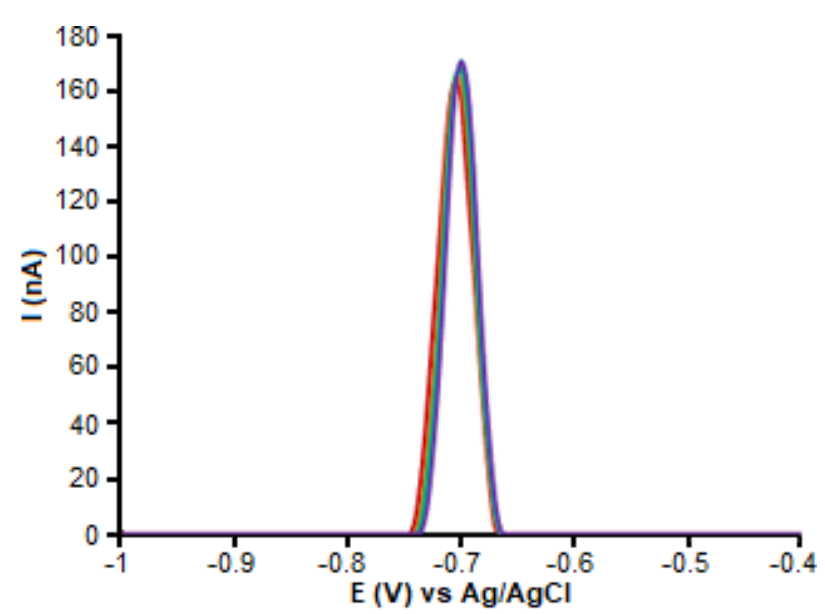

Fig 6. The voltammogram curve of the modified working electrode, measured 5 times at a concentration of $1.00 \times 10^{-7} \mathrm{M}$ and rate of $50 \mathrm{mV} / \mathrm{s}$ 
Table 3. Comparison of the value of correlation coefficients and the ability of the analysis of copper with UV-Vis spectrophotometry and voltammetry method

\begin{tabular}{ccccc}
\hline \multirow{2}{*}{ Metal Ion } & \multicolumn{2}{c}{ Linear measurement range } & \multicolumn{2}{c}{ Limit detection } \\
\cline { 2 - 5 } & $\begin{array}{c}\text { Voltammetry } \\
\text { method }\end{array}$ & $\begin{array}{c}\text { Spectrophotometry } \\
\text { method }\end{array}$ & $\begin{array}{c}\text { Voltammetry } \\
\text { method }\end{array}$ & $\begin{array}{c}\text { Spectrophotometry } \\
\text { method }\end{array}$ \\
\hline Copper(II) & 0.9654 & 0.9943 & $1.00 \times 10^{-11} \mathrm{M}$ & $2.36 \times 10^{-5} \mathrm{M}$ \\
\hline
\end{tabular}

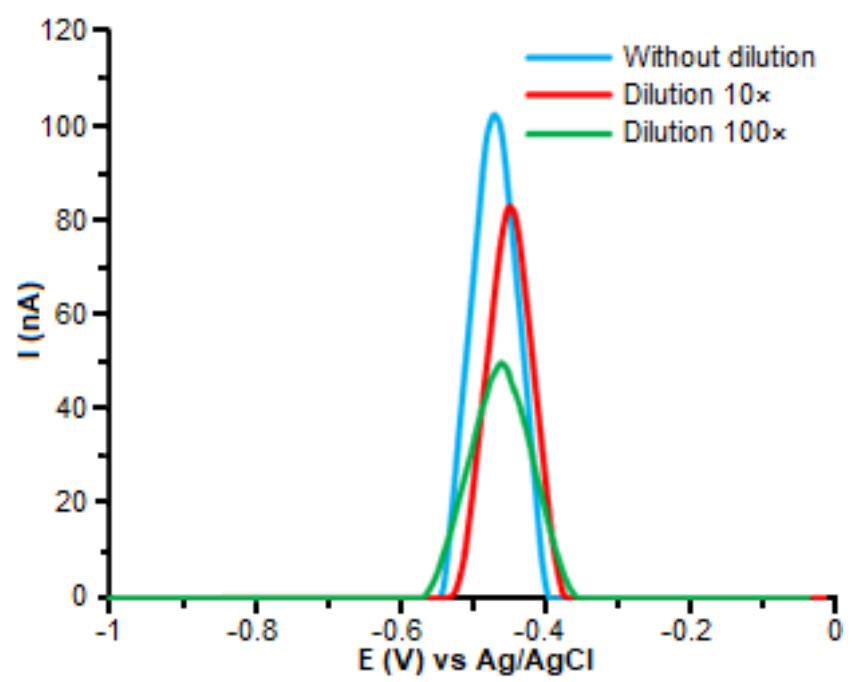

Fig 7. Voltammogram of copper(II) content in well water

The results of the measurements of the well water samples show that the copper content in well water was very small. According to the copper voltammogram, the current which was obtained from the analysis was above $100 \mathrm{nA}$.

\section{Comparison of the Validation Results}

The comparison of the validation result was aimed to determine the best method of determining copper(II), between the UV-Vis or the voltammetry spectrophotometry method. Comparison of the correlation coefficient and analytical ability for copper(II) for the UV-Vis spectrophotometry method and the voltammetry method can be seen in Table 3 .

The results of the study shows that the voltammetry method was better at measuring the content of copper(II) in solution and also in the well water compared to the UVVis spectrophotometry method. The more sensitive method (the lower the detection limit) demonstrate a better analysis process.

\section{- CONCLUSION}

Based on the current research, it can be concluded that the modification of the carbon paste electrodes by mixing with the modifier Na-diethyldithiocarbamate shows a very good peak current response to copper(II) solution. This is proven by the low detection limit of 1.00 $\times 10^{-11} \mathrm{M}$ and regression line equation $\mathrm{y}=10.265 \ln (\mathrm{x})$ +330.47 with $\mathrm{r}$ value of 0.9654 , optimum rate of $10 \mathrm{mV} / \mathrm{s}$, and stable repeatability (reproducible). In addition, the voltammetry method was found to be better than the UV-Vis spectrophotometry method for the analysis of copper(II) in solution and well water.

\section{- ACKNOWLEDGMENTS}

We would like to thank those who have contributed to our research, the team and the research assistants. We would also like to express gratitude to the Yogyakarta State University which was a pleasant place to conduct our research.

\section{- AUTHOR CONTRIBUTIONS}

Suyanta conducted the experiment and prepared the manuscripts. Ilyas Md. Isa provided the experiment materials. Regina Tutik Padmaningrum analyzed the data. Sunarto, Rahadian, Ilyas Md. Isa, Regina Tutik Padmaningrum revised the manuscript. Karlinda helped in carrying out the experiment. All authors agreed to the final version of this manuscript.

\section{- REFERENCES}

[1] Pratiwi, A., Yusuf, B., and Gunawan, R., 2015, Analisis perubahan kadar logam tembaga $(\mathrm{Cu})$ pada penambahan ion perak (Ag) dengan metode elektrokoagulasi, $J K M, 13$ (1), 1-3.

[2] Parmar, M., and Takur, L.S., 2013, Heavy metal Cu $\mathrm{Ni}$ and $\mathrm{Zn}$ : Toxicity, health hazards and their removal techniques by low cost adsorbents: A short overview, Int. J. Plant Anim. Environ. Sci., 3 (3), 2231-4490. 
[3] Kooh, M.R.R., Santos, J.H., and Dahri, M.K., 2013, Preparation and evaluation of Acetabulariamodified carbon paste electrode in anodic stripping voltammetry of copper and lead ions, J. Chem., 2013, 538012.

[4] Stankovic, D., Roglic, G., Mutic, J., Andjelkovic, I., Markovic, M., and Manojlovic, D., 2011, Determination of copper in water by anodic stripping voltammetry using $\mathrm{Cu}-\mathrm{DPABA}-\mathrm{NA} / \mathrm{GCE}$ modified electrode, Int. J. Electrochem. Sci., 6, 5617-5625.

[5] Ganjali, M.R., Norouzi, P., Shamsolahrari, L., and Ahmadi, A., 2006, PPb level monitoring of lanthanium by a novel PCV-membrane sensor based on 4-methyl-2-hydrazinobenzothiazole, Sens. Actuators, B, 114 (2), 713-719.

[6] Pandurangachar, M., Swamy, B.E.K., Chandrashekar, B.N., Gilbert, O., Reddy, S., and Sherigara, B.S., 2010, Electrochemical investigations of potassium ferricyanide and dopamine by 1-butyl-4methylpyridinium tetrafluoro borate modified carbon paste electrode: A cyclic voltammetric study, Int. J. Electrochem. Sci., 5, 1187-1202.

[7] Ensafi, A.A., and Karimi-Maleh, H., 2010, Modified Multiwall carbon nanotubes paste electrode as a sensor for simultaneous determination of 6thioguanine and folic acid using ferrocene dicarboxylic acid as a mediator, J. Electroanal. Chem., 640 (1-2) 75-83.

[8] Putra, B.R., Darusman, L.K., and Rohaeti, E., 2013, Carbon paste electrode hexadecyltrimethyl ammonium bromide modified natural zeolite for chromium(VI) detection, Indones. J. Chem., 13 (2), 122-128.

[9] Deswati, Suyani, H., Safni, Loekman, U., and Pardi, H., 2013, Simultaneous determination of cadmium, copper and lead in sea water by adsorptive stripping voltammetry in the presence of calcon as a complexing agent, Indones. J. Chem., 13 (3), 236-241.

[10] Thanh, N.M., Hop, N.V., Luyen, N.D., Phong, N.H., and Toan, T.T.T., 2019, Simultaneous determination of $\mathrm{Zn}(\mathrm{II}), \mathrm{Cd}(\mathrm{II}), \mathrm{Pb}$ (II), and $\mathrm{Cu}(\mathrm{II})$ using differential pulse anodic stripping voltammetry at a bismuth film-modified electrode, Adv. Mater. Sci. Eng., 2019, 1826148.

[11] Deswati, Suyani, H., and Safni, 2012, The method development of analysis $\mathrm{Cd}, \mathrm{Cu}, \mathrm{Pb}$ and $\mathrm{Zn}$ in sea water by absorptive stripping voltammetry (ASV) in the presence of calcon as complexing agent, Indones. J. Chem., 12 (1), 20-27.

[12] Adekunle, A.S., Arotiba, O.A., Agboola, B.O., Maxakato, N.W., and Mamba, B.B., 2012, Voltammetric and impedance studies of phenols and its derivatives at carbon nanotubes/Prussian blue films platinum modified electrode, Int. J. Electrochem. Sci., 7, 8035-8051.

[13] Madrakian, T., Haghshenas, E., and Afkhami, A., 2014. Simultaneous determination of tyrosine, acetaminophen and ascorbic acid using gold nanoparticles/multiwalled carbon nanotube/glassy carbon electrode by differential pulse voltammetric method, Sens. Actuators, B, 193, 451-460.

[14] Khan, R., Gorski, W., and Garcia, C.D., 2011, Nanomolar detection of glutamate at a biosensor based on screen-printed electrodes modified with carbon nanotubes, Electroanalysis, 23 (10), 23572363.

[15] Skoog, D.A., Holler, F.J., and Crouth, S.R., 2018, Principles of Instrumental Analysis, Textbook of Instrumental Analysis, $7^{\text {th }}$ Ed., Thomson Brook/Cole, California.

[16] Zubair, S., Asghar, F., Badshah, A., Lal, B., Hussain, R.A., Tabassum, S., and Tahir, M.N., 2019, New bioactive ferrocene-subsituted heteroleptic copper(I) complex: Synthesis, structural elucidation, DNA interaction, and DFT study, $J$. Organomet. Chem., 879, 60-68.

[17] Sirotiak, M., Bartošová, A., and Blinová, L., 2014, UV-Vis Spectrophotometric determinations of selected elements in modelled aqueous solutions, $J$. Environ. Prot. Saf. Educ. Manage., 3 (2), 75-87.

[18] Farahi, A., Lahrich, S., Achak, M., El Gaini, L., Bakasse, M., and El Mhammedi, M.A., 2014, Parameters affecting the determination of paraquat at silver rotating electrodes using differential pulse 
voltammetry, Anal. Chem. Res., 1, 16-21.

[19] Suyanta, Sunarto, Sari, L.P., Wardani, N.I., and Isa, I.M., 2014, Differential adsorptive stripping voltammetric determination of ultra trace lanthanum(III) based on carbon paste electrode modified with 3-methyl-2-hydrazinobenzothiazole, Int. J. Electrochem. Sci., 9, 7763-7772.

[20] Mohadesi, A., Teimoori, E., Taher, M.A., and Beitollah, H., 2011, Adsorptive stripping voltammetric determination of cobalt(II) on the carbon paste electrode, Int. J. Electrochem. Sci., 6, 301-308.

[21] Arancibi, V., Nagles, E., García-Beltrán, O., and Hurtad, J., 2018, Adsorptive stripping voltammetric determination of lead and cadmium in natural waters in the presence of rutin using a Nafion-mercury coated film electrode, Int. J. Electrochem. Sci., 13, 8711-8722.

[22] Wang, H.Y., Pan, M.I., Oliver Su, Y.L., Tsai, S.C., Kao, C.H., Sun, S.S., and Lin, W.Y., 2011, Comparison of differential pulse voltammetry
(DPV)-A new method of carbamazepine analysiswith fluorescence polarization immunoassay (FPIA), J. Anal. Chem., 66 (4), 415-420.

[23] Pratiwi, N.A., and Sunarto, 2018, Perbandingan validasi metode analisis ion tembaga (II) tanpa pengompleks dan dengan pengompleks $\mathrm{Na}-$ dietilditiokarbamat secara spektrofotometri UVVis, J. Kim. Das., 7 (3), 96-104.

[24] Helsel, M.E., and Franz, K.J., 2015, Pharmacological activity of metal binding agents that alter copper bioavailability, Dalton Trans., 44 (19), 8760-8770.

[25] Sandford, C., Edwards, M.A., Klunder, K.J., Hickey, D.P., Li, M., Barman, K., Sigman, M.S., White, H.S., and Minteer, S.D., 2019, A synthetic chemist's guide to electroanalytical tools for studying reaction mechanism, Chem. Sci., 10 (26), 6404-6422.

[26] Silva, T.A., Wong, A., and Fatibello-Filho, O., 2020, Electrochemical sensor based on ionic liquid and carbon black for voltammetric determination of Allura red colorant at nanomolar levels in soft drink powders, Talanta, 209, 120588. 